\title{
KONSEP MASLAHAH MENURUT IMAM MALIK DAN AL- TUFI \\ (STUDI KOMPARATIF TENTANG MASLAHAH IMAM MALIK DAN NAJM AL-DIN AL-TUFI)
}

\author{
Oleh: Imas Setiyawan \\ Email: imassetiyawan@staitaruna.ac.id
}

(STAI Taruna)

\begin{abstract}
Among the sources of Islamic law which is still disputed by scholars' argument is maslahah. Some scholars reject it, but most agree make maslahah as one of the sources of Islamic law in matters of ijtihad. Imam Malik considered as a pioneer scholar who makes maslahah as one source of law ijtihadnya. His view was followed by the scholars 'other, one of whom is Najm alDin al-Tufi, a cleric' Hambali. However, the twoleaders of thought are not the same, even in certain cases the difference is very sharp, although in certain parts have in common. In the view of Malik, maslahah serve as asource of Islamic law in matters which are not discussed formally by nas and ijma ', butmust not conflict with the spirit of the passage as a whole. In contrast, alTufi maslahahgood use in the problem discussed by nat/ijma', or not. As for the area applications maslahah, both agree that that maslahah only be used in matters mu'amalah.
\end{abstract}

Keyword: maslahah, law, Islam, the source

\section{A. Pendahuluan}

Ada dua macam kategori hukum Islam, yaitu syari'ah dan fiqh. Syari'ah adalah hukum Islam yang ditegaskan secara langsung oleh nas Al-Qur'an dan atau hadist, sedangkan fiqh adalah hukum Islam yang dihasilkan oleh ijtihad.Hukum Islam kategori syari'ah bersifat 1 universal, baik dalam nilai maupun sistemnya. Ia berlaku sampai kapan pun, di manapun dan dalam kondisi apapun. Syari'ah murni bersumber dari wahyu, karena itu tidak ada peluang bagi manusia untuk memasuki wilayah ini. Termasuk dalam kategori ini adalah masalah akidah, sistem nilai, dan beberapa hukum amaliah. Sedangkan sumber fiqh merupakan kombinasi antara wahyu dan akal manusia. Karena itu universalisme ajaran ini hanya terletak pada nilainya, yaitu kemaslahatan, sementara sistemnya bersifat partikular. Peristiwa qawl qadim dan qawl jadid-nya Imam al-Syafi'i merupakan salah satu bukti partikularistik fiqh dalam hal sistem. ${ }^{2}$

Hukum Islam baik syari'ah maupun fiqh ditujukan untuk mewujudkan kemaslahatan dalam kehidupan manusia. ${ }^{3}$ Tidak ada seorang muslimpun yang membantah dalam hal ini. AlQur'an sendiri secara tegas mengatakan bahwa Islam adalah rahmat bagi sekalian alam

\footnotetext{
${ }^{1}$ Ijtihad adalah upaya yang dilakukan ulama' dalam mencari kesimpulan hukum

2 "Atho Mudzhar, "Universalisme Islam dan Kehidupan Modern" (Makalah dalam Seminar "Islam dan Sekularisi", BPKM-IIQ, Jakarta, 16 september 1990).

${ }^{3}$ Abd al-Wahhab Khallaf, Ilm Usul al-Fiqh (Kuwait: Dar al-Kuwaitiyah, 1968), 197. 
(Q.S.21:107). Karena itu, tema sentral dari hukum Islam diformasikan dengan jalb al-maslahah wa daf' al-mafsadah (menarik kemaslahatan dan menolak kerusakan). ${ }^{4}$

Maslahah sebagai titik sentral dari hukum Islam selalu menjadi pijakan dalam setiap penetapan hukum. Ia merupakan jiwa dari hukum Islam itu sendiri. Karena itu pada upaya mewujudkan kemaslahatan itulah sebenarnya yang menjadi 'kekuatan' hukum Islam sehingga hukum Islam menjadi fleksibel dan mampu menjawab setiap persoalan yang muncul seiring dengan perkembangan peradaban manusia.

Namun demikian, menjadikan maslahah sebagai sumber hukum Islam (baca: fiqh), masih diperselisihkan oleh para ulama'. Imam al Syafi'i dan Imam Abu Hanifah pun tidak mencantumkan maslahah dalam sumber hukum ijtihadnya. ${ }^{5}$ Imam al-Ghazali bahkan secara keras mengecamnya sebagai sebuah tindakan 'membuat syara' (man istaslah faqad syarra). ${ }^{6}$

Berbeda dengan al-Syafi'i ataupun Abu Hanifah, Imam Malik dikenal sebagai pemilik konsep maslahah sebagai sumber hukum Islam. Ia menempatkannya pada posisi ketujuh dalam hirarki sumber hukum ijtihadnya. ${ }^{7}$ Dalam pandangan Malik, maslahah dijadikan sebagai sumber hukum dalam persoalan-persoalan yang tidak dibicarakan secara formal oleh nas (AlQur'an dan hadist) ataupun ijma', ${ }^{8}$ tetapi tidak boleh bertentangan dengan jiwa nas secara keseluruhan. ${ }^{9}$

Pandangan Malik banyak mendapat dukungan dari ulama' lain, salah satu di antaranya adalah Najm al-Din al-Tufi, seorang ulama' penganut mazhab Hambali. ${ }^{10}$ Namun demikian, ia muncul dengan membawa satu tawaran konsep mas\}lah\}ah yang baru dan berbeda dengan konsep maslahah Malik yang menjadi acuan ulama' pendukung maslahah lainnya. Dalam pandangan al-Tufi, jika terjadi pertentangan antara nas/ijma' di satu pihak, dengan maslahah di pihak lain, maka maslahah harus didahulukan. ${ }^{11}$

\footnotetext{
${ }^{4}$ Ibid., 198.

5 Muhammad Idris al-Syafi'i, al-Risalah (t.t.: Dar al-Fikr, t.t), 21 dan seterusnya. Lihat juga Muhammad MusaTowana, al-Ijtihad wa Mada Hajatina Ilayh fi hadha al- 'Asr (t.t.: Dar al-Kutub al-Hadithah,t.t.), 5964. namun demikian, sebagian ulama' menyaksikan bahwa Hanafi dan Syafi'i 'anti maslahah'. Selengkapnya akan dibahas di pembahasan.

${ }^{6}$ Abu Hamid bin Muhammad bin Muhammad al-Ghazali, al-Mustafa (Bairut: Dar al-Kutub al-'Ilmiyah, t.t.) 197. dalam pandangan Islam, pembuat hukum yang hakiki adalah Allah. Adapun para mujtahid, hanyalah dalam rangka 'menerjemah' hukum yang dikehendaki oleh Allah. Karena itu hukum yang 'dihasilkan' oleh mujtahid hanyalah sampai pada tingkatan zann (dugaan kuat). Sementara Rasul-pun juga 'hanya' berbicara berdasarkan wahyu. Selengkapnya lihat di Khallaf, 'Ilm, 96. lihat juga Jalal al-Din al-Ma halli, Syarh al-Waraqat (Semarang: Maktabah Usaha Keluarga, t.t.),237.

${ }^{7}$ Ibid., 73.

8 'Abd al-Wahhab Khallaf, Masadir al-Tashri' al-Islami fi Ma La Nass Fih (Kuwait: Dar al-Qalam, 1972) 89.

${ }^{9}$ Muhammad Abu Zahrah, Ushul al-Fiqh (t.t: Dar al-Fikr al'Arabi, t.t.), 279.

10 Tentang madhhab yang dianut oleh al-Tufi, banyak diragukan oleh para ulama'. Selengkapnya akan dibicarakan pada pembahasan.

${ }^{11}$ Najm al-Din al-Tufi, "Risalah al-Maslahah” dalam al-Manar, vol. 9, juz 10,ed. Muhammad Rasyid Rida (Mesir; al-Manar, 1324 Hukum / 1906 M), 753-4. 
Gagasan ini merupakan sebuah gagasan berani dan sangat tidak populer karena telah melanggar rambu yang selama ini menjadi kesepakatan para ulama' bahwa dalam menetapkan hukum, maka nas dan ijma' harus didahulukan. ${ }^{12}$ Tak heran jika kemudian gagasan itu melahirkan gelombang kecaman yang luar biasa. Tidak kurang dari 'Abd al-Wahhab Khallaf yang menudingnya sebagai orang yang membuka pintu penghancuran terhadap nas-nas. ${ }^{13} \mathrm{Al}-$ Kawthari bahkan dengan sadis menyebutnya sebagai orang pertama yang membuka pintu kejahatan. ${ }^{14}$ Namun demikian, pada sisi berseberangan, teori al-Tufi juga mendapat dukungan. Di antara pendukungnya bahkan ada yang menjadikannya sebagai pijakan bagi ide-ide pembaharuan hukum Islam.

\section{B. Aplikasi Maslahah dalam Hukum Islam}

Di kalangan ulama' ada semacam konsensus untuk membagi hukum Islam menjadi dua, yaitu ibadah dan mu'amalah. Ibadah adalah hukum yang mengatur hubungan manusia dengan Tuhannya. Termasuk dalam kategori ibadah adalah muqaddarat (hukum yang telah ditentukan kadarnya), seperti ketentuan dalam waris, masa 'iddah, dan lain-lain. Untuk kategori ini mereka sepakat bahwa nas-nas-nya tidak memiliki 'illat. Artinya, manusia tidak boleh menganalisa alasan dan tujuan ditetapkannya suatu hukum dalam bidang ini. Karena itu, seorang mukallaf tidak boleh mewajibkan sesuatu yang tidak diwajibkan atas dirinya, dengan alasan ada kesamaan 'illat dan hikmah di dalamnya dengan ibadah lain yang ditetapkan oleh nas. Dengan demikian maka kewajiban manusia adalah meyakini bahwa hukum-hukum ibadah itu dalam rangka mewujudkan kemaslahatan manusia. ${ }^{15}$

Ketegasan Malik dalam hal ini sama dengan ketegasan para ulama' lain. Dalam pandangannya, nas-nas tentang ibadah harus dipahami secara tekstual. Manusia tidak boleh membuat keputusan hukum tentang ibadah atas dasar pertimbangan maslahah, walaupun menurut jangkauan akalnya hal tersebut dapat mewujudkan maslahah. Misalnya, bersuci harus dilakukan dengan menggunakan air mutlak, walaupun ada alat lain yang dapat digunakan dan dipastikan hasilnya bersih.

Dalam persoalan ibadah, kemampuan akal manusia tidak akan mengantarnya untuk sampai kepada petunjuk yang dibutuhkannya. Karena itu, seringkali ketentuan-ketentuan ibadah terkesan 'tidak rasional'. Contoh, ketentuan-ketentuan tentang taharah (bersuci). Jika seseorang buang air kecil atau besar dalam keadaan wudu', ia diwajibkan untuk menyucikan

\footnotetext{
${ }^{12}$ Khallaf, ' $I l m, 21$.

${ }^{13}$ Khallaf, Masadir, 101.

${ }^{14}$ Husain Hamid Hasan, Nazariyat al-Maslahah fi al-Fiqh al-Islami (Beirut: Dar al-Nahdah al-“Arabiyah, 1971), 529 pada catatan kaki no. 1 .

${ }^{15}$ Zahra, Malik, 298. lihat juga Khallaf, Masadir, 89.
} 
seluruh anggota wudhu', tidak hanya terbatas pada qubul dan dubur saja sebagai tempat keluarnya najis tersebut. Ia juga tidak diharuskan menyucikan seluruh anggota tubuh. Sementara jika seseorang haid atau keluar air mani, maka ia diharuskan menyucikan seluruh anggota tubuh. Tidak hanya terbatas pada tempat keluarnya darah atau mani tersebut, dan juga tidak terbatas pada anggota wudhu' saja. Contoh lain, hubungan antara shalat dengan waktunya. Begitu juga 'alasan' dijadikannya tanah sebagai pengganti air dalam bersuci, dan lain-lain. ${ }^{16}$

Adapun kategori kedua adalah mu'amalah, yaitu hukum yang mengatur hubungan antar manusia. Untuk bidang ini, yang dijadikan sebagai pijakan dalam penetapan hukum adalah maslahah serta alasan ditetapkannya hukum tersebut. Sudah menjadi kesepakatan ulama' bahwa taklif dalam bidang ini ditujukan untuk menciptaan masyarakat Islam yang sejahtera dan damai dengan dasar keadilan dan keutamaan,17 dengan alasan:

1. Berdasarkan penelitian, tujuan Syari' adalah untuk mewujudkan kemaslahatan bagi hamba-hambanya. Sementara hukum mu'amalah selalu berputar mengikuti perputaran maslahah. Karena itu, selalu terlihat bahwa suatu hal yang tidak bernilai maslahah dilarang, sementara yang bernilai maslahah diperbolehkan. Contoh: pensyari'atan jual beli, larangan riba, larangan bagi hakim memutuskan perkara dalam keadaan marah, dan lainlain.

2. Syari' selalu memberi penjelasan yang gamblang terhadap 'illat-'illat hukum mu'amalah dan adat. Sementara 'illat-'illat hukum tersebut adalah sifat-sifat yang dapat mewujudkan kemaslahatan dan bersifat rasional. Hal tersebut menunjukkan bahwa Syari' menghendaki kita mengikuti maknanya, tidak berhenti hanya pada teksnya kecuali dalam bidang ibadah.

3. Berpatokan pada maslahah telah berlaku sejak masa-masa fatrah (masa dimana tidak ada rasul karena rasul berikutnya belum muncul). Secara umum terbukti bahwa kehidupan mereka dapat berjalan dengan baik. Syari'ah kemudian datang untuk menyempurnakan akhlak dan adat yang selama ini menjadi landasan kehidupan mereka. Karena itu, Islam mengakui sejumlah hukum yang berlaku di masa jahiliyah, seperti diyat, sumpah, akad qirad, dan lain-lain. ${ }^{18}$

Al-Tufi sepakat dalam hal ini. Menurutnya, ruang lingkup maslahah hanyalah dibidang mu'amalah dan adat. Adapun dalam bidang ibadah dan muqaddarat (hukum yang telah ditentukan kadarnya) merupakan hak Syari' sepenuhnya yang tidak dapat dijangkau oleh akal manusia, baik bentuk, kadar, maupun tempat dan waktunya. Karena itu, rujukan hukum

\footnotetext{
${ }^{16}$ Al-Shatibi, al-I'tisam, vol. 2, 130-2.

17 Zahrah, Malik, 298.

${ }^{18}$ Al-Shatibi, al-Muwafaqat, vol. 2, 212.

137
} 
dalam ibadah adalah nas dan ijma'. Dalam ibadah, seorang hamba harus melakukan sesuai ketentuan dari-Nya, sebab seorang pesuruh tidak bisa disebut taat, kecuali jika ia melaksanakan perintah atasannya sesuai dengan apa yang diperintahkannya serta melakukan apa yang diketahuinya dikehendaki oleh tuannya. Karena itu, jika seseorang mencoba untuk 'merasional'kan syara' (ibadah), maka bisa dipastikan bahwa mereka sesat dan menyesatkan. Hal ini berbeda dengan hak-hak mukallaf. Hukum terhadap mereka adalah siyasah syar'iyah yang ditujukan untuk kemaslahatan mereka, karena itu maka maslahah yang dijadikan sebagai pijakan. ${ }^{19}$

\section{Peran Akal dalam Menentukan Maslahah}

Sekalipun Malik berpendapat bahwa maslahah dijadikan sebagai rujukan utama dalam persoalan mu'amalah, namun, sebagaimana disebutkan di atas bukan berarti maslahah tersebut tidak memiliki keterkaitan dengan nas sama sekali. Dalam pandangan Malik, maslahah dijadikan sebagai dalil hukum jika sejalan dengan tujuan Syari' dengan tidak menyalahi prinsip-prinsip syari'ah serta dalil-dalil yang telah ditetapkan-Nya. ${ }^{20}$ Sementara untuk mengetahui tujuan Syari' baik berupa perlindungan terhadap agama, jiwa, akal, keturunan, dan harta, dilakukan melalui penelitian yang mendalam berdasarkan informasi dari nas dan ijma'.

Namun demikian, kesimpulan bahwa suatu maslahah merupakan maslahah yang menjadi tujuan Syari' dalam persoalan yang tidak dibicarakan secara formal oleh nas, tidak bisa didasarkan pada satu dalil ataupun satu sudut pandang saja. Kesimpulan terhadap tujuan Syari' tersebut diperoleh berdasarkan nas-nas yang berbentuk umum, mutlak, muqayyad, dan lain-lain, dari berbagai peristiwa serta persoalan yang bermacam-macam..$^{21}$

Contoh, rakyat boleh mengangkat seorang kepala negara (al-Imamah al-Kubra) yang tidak berkualitas mujtahid. Hal ini untuk menghindari kemungkinan munculnya bahaya yang lebih besar jika masyarakat dibiarkan dalam keadaan tidak memiliki pemimpin. Tidak ada nas khusus yang membicarakan persoalan ini. Tetapi beberapa nas membicarakan tentang keharusan kita menghindari bahaya yang lebih besar. Misalnya pensyari'atan jihad yang didalamnya mengandung bahaya terhadap jiwa, hukum bunuh bagi orang yang ingkar zakat, hukum bunuh bagi pemberontak, dan lain-lain. Sementara tidak adanya pemimpin merupakan bahaya yang jauh lebih besar dibandingkan bahaya memilih seorang pemimpin yang tidak berkualitas mujtahid. Di samping itu, adanya seorang kepala negara merupakan maslahah daruri, sementara syarat sebagai mujtahid adalah mas\}lah\}ah tahsini/takmiliyah. Ketika terjadi

\footnotetext{
$\left.{ }^{19} \mathrm{Al}-\mathrm{T}\right\} \mathrm{u}>\mathrm{fi}>$, Risa $>$ lah, 764,9.

${ }^{20}$ Al-Shatibi, al-I'tisam, vol. 2, 39.

${ }^{21}$ Al-Shatibi, al-Muwafaqat, vol. 2, 39. 138
} 
pertentangan antara maslahah yang berkualitas daruri dengan maslahah yang berkualitas tahsini, maka maslahah daruri yang harus didahulukan.

Contoh lain adalah hukum qisas diberlakukan terhadap sejumlah orang karena membunuh satu orang. Ketentuan semacam ini pernah pula difatwakan oleh 'Umar bin alKhattab. Dalam persoalan ini juga tidak ada nas khusus yang membicarakannya. Tertapi ia termasuk dalam kategori 'melindungi jiwa' yang dalil-dalilnya tersebar di beberapa tempat. Alasan Malik adalah karena korban adalah ma'sum dan dibunuh dengan sengaja. Membiarkan pembunuh tanpa dihukum qisas akan menyebabkan hukum qisas terabaikan. Sangat mungkin setiap orang yang bermaksud membunuh orang lain mencari bantuan untuk menghindar dari hukum qisas sehingga nyawa manusia terancam. ${ }^{22}$

Karena itu, al-Shatibi tegas-tegas mengatakan bahwa ketentuan maslahah dan mafsadah tidak bisa dilihat berdasarkan hukum adat/kebiasaan.23 Dalil akal jika digunakan dalam persoalan ini haruslah dengan mengikuti dalil sam'iyah (naql/nas), atau ia berperan untuk merumuskan metode dalam memahami nas, atau yang semacamnya. Ia tidak berdiri sendiri, sebab persoalannya adalah persoalan syar'i, sementara akal bukan Syari'. ${ }^{24}$ Dengan demikian, jelas bahwa maslahah mursalah Malik adalah maslahah yang tidak menyimpang dari nas, sebab ia merupakan salah satu bentuk memahami nas. Karena itu pula, tidak akan terjadi kontradiksi antara maslahah dengan nas tertentu, baik nas tersebut dalalahnya zanni (memiliki arti lebih dari satu), ataupun qat'i (tidak bisa diartikan pada arti lain). Jika terjadi kontradiksi antara maslahah dengan nas, berarti ia bukan maslahah mursalah, karena telah merusak makna irsal-nya. ${ }^{25}$

Al-Tufi tidak menolak bahwa maslahah haruslah sesuai dengan tujuan Syari' sebagaimana terlihat dalam definisi maslahah yang dikemukakannya. Perbedaannya dengan Malik adalah ketika mengemukakan cara untuk mengetahui apakah suatu maslahah merupakan tujuan Syari' atau bukan. Dalam pandangan al-Tufi, akal sehat manusia cukup memiliki kompetensi untuk menentukan apa itu maslahah dan apa itu mafsadah sepanjang dalam batas mu'amalah. Keberadaan maslahah dapat ditujukan dengan pembuktian empirik melalui hukum-hukum kebiasaan. ${ }^{26}$ Menurutnya, Allah telah menciptakan 'sarana' bagi kita untuk mengetahui seluk beluk kemaslahatan kita sendiri. Dengan demikian, kita tidak perlu

\footnotetext{
${ }^{22}$ Al-Shatibi, al-I'tisam, vol. 2, 125-6.

${ }^{23}$ Al-Shatibi, al-Muwafaqat, vol. 2, 29.

${ }^{24}$ Ibid., vol. 1, 23-4.

${ }^{25}$ Hassan, Nazariyah, 107.

${ }^{26}$ Al-Tufi, "Risalah", 770. 
merujuk pada spekulasi nas yang amat abstrak yang hanya menghasilkan kesimpulan 'kemungkinan menghasilkan maslahah dan kemungkinan tidak'. ${ }^{27}$

Al-Tufi sebagaimana disebutkan diatas dengan tegas menolak membagi maslahah menjadi mu'tabarah mulghah, dan mursalah. Artinya, ketentuan tentang maslahah tidak memiliki ketergantungan pada nas sama sekali. Dengan demikian berarti kehujjahan maslahah tidak memerlukan konfirmasi dari nas, sehingga ia muncul sebagai sebuah dalil hukum yang berdiri sendiri.

Metode untuk mengetahui maslahah yang dikemukakannya bukan tidak memiliki kekurangan. Ketika mengemukakan teorinya yang ketiga, yaitu jika suatu perbuatan mengandung maslahah dan mafsadah sekaligus dengan kadar yang seimbang seperti tidak adanya penutup aurat kecuali hanya cukup untuk salah satu dari dua kemaluan saja, kita bisa memilih untuk menutup dubur atau qubul, mendapat sorotan dari Mustafa Zayd. Menurutnya, qubul adalah aurat yang lebih bersifat khusus, karena itu menutupnya jelas lebih utama. Artinya, dalam hal ini kadar maslahah dan mafsadahnya tidaklah seimbang. Disamping itu sangat layak dipertanyakan, mungkinkah terjadi peristiwa sebagaimana yang dicontohkan oleh al-Tufi tersebut?

Ibn Qayyim al-Jawziyah, seorang ulama' Hanbali sebagaimana dikutip oleh Zayd bahkan dengan tegas mengatakan bahwa tidak ada perbuatan yang mengandung maslahah sekaligus mafsadah dengan kadar yang sama. Jika perbuatan semacam itu kemudian dianggap lebih layak untuk dikerjakan, berarti maslahahnya lebih unggul. Sebaliknya, jika meninggalkan perbuatan tersebut dianggap lebih baik, berarti mafsadahnya yang lebih besar. Disamping itu, dalam penelitiannya tidak ada dalil yang berbicara tentang suatu perbuatan yang memiliki kadar maslahah dan mafsadah yang seimbang. Sebab, maslahah dan mafsadah adalah dua kubu yang berseberangan, sehingga mustahil untuk bersatu. Jika keduanya bertemu, dapat dipastikan bahwa salah satunya lebih unggul. Dengan demikian, maka hukum didasarkan pada yang lebih unggul tersebut. ${ }^{28}$

Membaca pendapat al-Tufi tentang kekuatan dan kemandirian akal dalam menentukan maslahah dan mafsadah bagaimanapun melahirkan suatu pertanyaan, sebab ajaran tersebut merupakan ajaran $\mathrm{Mu}^{\prime}$ tazilah, ${ }^{29}$ sementara ia dianggap sebagai penganut Hambali. Bahkan ia juga secara tegas menyatakan dirinya sepakat dengan ajaran Ash'ari. Disamping itu, ia juga terkesan sangat pragmatis, bahkan gegabah serta terlalu menyederhanakan persoalan.

\footnotetext{
${ }^{27}$ Ibid., 7623.

${ }^{28}$ Zayd, al-Maslahah, 140-1

${ }^{29}$ Harun Nasution, Teologi Islam, Aliran-Aliran, Sejarah, Analisa, Perbandingan, (Jakarta: UI-Press, 1986$), 80$. 140
} 


\section{Kualifikasi Maslahah sebagai Sumber Hukum}

Seluruh ummat bahkan seluruh agama sepakat bahwasanya syari'ah datang untuk memberikan perlindungan terhadap lima persoalan asasi, yaitu: agama, jiwa, akal, keturunan, dan harta. Tidak ada dalil khusus yang menyatakan hal tersebut, tetapi kesimpulan itu dihasilkan dari sejumlah dalil sehingga dapat dipastikan kebenarannya. ${ }^{30}$

Perlindungan terhadap lima persoalan asasi ada yang berkualitas daruri, ada yang berkualitas haji, dan ada yang berkualitas tahsini. Pembagian ini disesuaikan dengan arti penting dan bahayanya. Perlindungan terhadap agama, jiwa, akal, keturunan, dan harta yang berkualitas daruri dilihat dari sisi upaya merealisasikan serta memelihara kelestariannya, masing-masing seperti kewajiban menjalankan rukun Islam dan kewajiban jihad, kebolehan makan segala jenis makanan yang halal dan pensyari'atan qisas, kebolehan minum segala jenis minuman yang tidak merusak akal dan pensyari'atan hukum pukul bagi peminum khamr, pensyari'atan nikah dan hukum pukul bagi pelaku zina serta pensyari'atan berbagai jenis mu'amalah dan hukum potong tangan bagi pencuri. Pengabaian terhadap jenis kemaslahatan ini akan menyebabkan hidup manusia hancur. Di antara ayat-ayat yang menunjukkan hal tersebut adalah Q.S. 6:151-3, 17-32, 60:12, dan lain-lain.

Adapun upaya perlindungan terhadap agama, jiwa, akal, keturunan, dan harta yang berada pada tingkatan haji, masing-masing seperti pensyari'atan beberapa rukhsah dalam shalat dan puasa, bolehnya berburu dan menikmati makanan yang lezat, bolehnya beberapa jenis transaksi dalam mu'amalah seperti akad qirad dan salam, serta pensyari'atan talak. Sementara upaya perlindungan terhadap agama, jiwa, akal, keturunan, dan harta yang berkualitas tahsini masing-masing seperti kewajiban menutup aurat, tata cara makan dan minum, larangan membeli barang-barang najis, serta tatakrama hubungan suami istri. ${ }^{31}$

Maslahah haji berangkat dari upaya untuk menghilangkan kesulitan dalam kehidupan manusia. Menghilangkan kesulitan merupakan tujuan Syari' ${ }^{32}$ Beberapa ayat Al-Qur'an yang menunjukkan hal tersebut di antaranya adalah Q.S. 5:6, 22:78, 2:185.

Dalam pandangan Malik, maslahah yang dijadikan sebagai dalil hukum adalah maslahah yang berkualitas daruri, dan haji. Perlindungan terhadap maslahah daruri ini, fungsi maslahah adalah sebagai 'media', bukan tujuan. Sementara dalam perlindungan terhadap maslahah haji adalah dalam rangka 'meringankan', bukan 'pengukuhan'. ${ }^{33}$

\footnotetext{
${ }^{30}$ Al-Shatibi, al-Muwafaqat, vol. 2, 8. lihat juga al-Yubi, Maqasid, 183.

${ }^{31}$ Al-Buti, Dawabit. Lihat juga Wahbah al-Zuhayli, Konsep Darurat Dalam Hukum Islam, Studi Banding Dengan Hukum Positif, Said Agil Husain al-Munawwar dan Hadri Hasan, (Jakarta: Gaya Media Pratama, 1997 H), 51-5.

${ }^{32}$ Salih bin 'Abd bin Hamid, Raf' al-Haraj, (Makkah: Jami’ah Umm al-Qura, 1403 H), 93.

${ }^{33}$ Al-Shatibi, al-I'tisam, 129. 
Malik menolak menjadikan mas\}lah\}ah yang berkualitas tahsini sebagai dalil hukum. Dalam pandangannya, maslahah yang berkualitas tahsini bisa dijadikan sebagai dalil hukum jika ada nas yang bersifat khusus yang mengakuinya. Hal itu bisa dipahami mengingat meninggalkan maslahah tahsini tidak akan menyebabkan kehidupan manusia menjadi hancur ataupun dilanda kesulitan. ${ }^{34}$

Contoh maslahah mursalah Malik yang berkualitas daruri adalah pemberlakuan hukum qisas terhadap sejumlah orang yang bersama-sama membunuh satu orang. Adapun contoh maslahah mursalah Malik yang berkualitas haji adalah jaminan atas barang pesanan dari produsen. Pada masa al-Khulafa' al-Rasyidun, 'Ali bin Abi Thalib mengatakan: "manusia tidak bisa maslahah tanpa adanya transaksi pesanan (istisna')". Artinya, masyarakat membutuhkan keberadaan seorang ahli industri yang akan memproduksi barang-barang kebutuhan mereka. Pada umumnya, mereka cenderung mengabaikan kepentingan konsumen, sehingga tidak jarang terjadi barang-barang pesanan sampai ke tangan konsumen dalam keadaan cacat. Jika hal tersebut diabaikan, maka akan sangat merugikan masyarakat. Tetapi jika harus menghapuskan jenis transaksi pesanan, masyarakat akan mengalami kesulitan yang jauh lebih besar. Karena itu, jaminan atas barang yang telah dipesan tersebut dipandang sebagai suatu kemaslahatan.

Keputusan ini tidak bisa dipandang sebagai hukuman kepada sang produsen atas kesalahan yang bisa jadi tidak dilakukannya. Bagaimanapun dia adalah orang yang bertanggung jawab atas transaksi yang telah dibuatnya. Dengan demikian, hal ini termasuk bagian dari mendahulukan kemaslahatan umum atas kemaslahatan khusus yang dalil-dalilnya tersebar di beberapa tempat. ${ }^{35}$

Berbeda dengan Malik, al-Tufi tidak membedakan apakah suatu maslahah berkualitas daruri, haji, ataupun tahsini, sebab ia menolak pembagian tersebut. Dengan demikian, berarti maslahah yang dijadikan sebagai dalil hukum oleh al-Tufi adalah jenis maslahah dengan kualitas apapun. Sepanjang ia dinilai maslahah, maka ia sah dijadikan sebagai dalil hukum.

\section{E. Otoritas Maslahah di Hadapan Nas dan Ijma'}

Dalam pandangan Malik, maslahah dijadikan sebagai sumber hukum dalam persoalanpersoalan yang tidak dibicarakan secara formal oleh nas dan ijma' tapi tidak boleh bertentangan dengan jiwa nas secara keseluruhan. Karena itu, ketika suatu peristiwa sudah

\footnotetext{
${ }^{34}$ Al-Yubi, Maqasid, 329.

${ }^{35}$ Al-Shatibi, al-I'tisam, vol. 2, 119. lihat juga Hamid, Raf, 315.

142
} 
dibicarakan oleh nas/ijma', maka maslahah tidak digunakan. ${ }^{36}$ Menurut al-Shatibi, jika terjadi pertentangan antara akal dengan naql, maka naql yang harus diikuti, dengan alasan:

1. Jika akal boleh membatalkan naql, maka batasan-batasan yang ditentukan oleh naql, tidak ada gunanya. Dan hal ini, batal dalam pandangan syari'ah.

2. Dalam ilmu kalam, akal tidak memiliki kewenangan untuk menentukan baik dan buruk, sebab jika boleh, maka akal menjadi penentu baik dan buruk.

3. Jika akal boleh menentukan baik dan buruk, maka agama boleh dibatalkan oleh akal. Artinya, nas syari'ah memberikan batasan-batasan terhadap perbuatan mukallaf, ucapanucapan, serta kepercayaan mereka. Jika akal memiliki kewenangan untuk melanggar batasan-batasan ini, berarti akal memiliki kewenangan untuk membatalkan seluruh ajaran agama. Dan hal ini jelas tidak benar. Karena itu, maka akal tidak boleh melakukan takhsis. ${ }^{37}$ Sementara kalangan menilai bahwa Malik men-takhsis nas-nas 'am dengan maslahah, serta mendahulukan maslahah atas khabar ahad. Pendapat tersebut tidak benar. Berdasarkan penelitian al-Buti, sikap Malik dalam menghadapi khabar ahad adalah sebagai berikut:

1. Mendahulukan zahir Al-Qur'an atas khabar ahad, kecuali jika khabar ahad tersebut didukung oleh dalil lain. Contoh, Malik mendahulukan zahir Q.S. 6: 145, daripada hadist Rasulullah yang melarang makan binatang buas. Karena itu, ia membolehkan makan binatang buas. Dalam Bidayat al-Mujtahid disebutkan bahwa jumhur ulama' berpendapat binatang buas dari jenis burung, hukumnya halal. Hanya saja sebagian ulama' menghukuminya dengan haram berdasarkan hadits tersebut. Perlu dijelaskan bahwasanya hadits tersebut tidak diriwayatkan oleh Bukhari Muslim. ${ }^{38}$

2. Meninggalkan setiap khabar ahad dan yang semisalnya yang zanni jika menyalahi prinsipprinsip umum syari'ah yang $q a t^{\prime} i$, atas dasar bahwa hadith tersebut diragukan berasal dari Nabi. Sementara prinsip-prinsip syari' ah tersebut didasarkan pada nas-nas yang tegas, baik dari Al-Qur'an maupun hadits-hadits mutawatir. Hal ini didasarkan pada sikap 'A'isyah yang menolak hadits yang menyatakan bahwa setiap mayat akan dihukum karena tangisan keluarganya. Hadits tersebut dinilainya menyalahi Q.S. 53:38-9. Sejalan dengan hal tersebut, Malik menolak bahwa ahli waris harus mengganti puasa pewarisnya jika ia punya hutang puasa, karena bertentangan dengan ayat di atas. Malik juga menolak hadits yang memerintahkan membasuh jilatan anjing dengan air tujuh kali, dimana salahsatunya

\footnotetext{
${ }^{36}$ Ijma' adalah dalil qat'i. Persoalan yang telah 'diputuskan' oleh ijma' tidak boleh dimasuki oleh Ijtihad. Dari sisi ini maka kekuatannya menyamai nass. Selengkapnya lihat di Khallaf, Ilm, 46.

${ }^{37}$ Al-Shatibi, al-Muwafaqat, vol. 1, 61-3.

${ }^{38}$ Abu al-Walid Muhammad bin Ahmad bin Muhammad bin Ahmad bin Rushd al-Qurtubi al-Andalusi, Bidayat alMujtahid wa Nihayah al-Muqtasid, (t.t.:Dar al-Kutub al-Islamiyah, t.t.), vol. 1, 343. lihat juga al-Shatibi, alMuwafaqat, vol. 3, 15
} 
dicampur dengan tanah, berdasarkan ayat Al-Qur'an yang membolehkan makan binatang buruan (Q.S. 5:4). Malik berkata: “Hadist itu datang, sementara saya tidak tahu hakikatnya. Buruannya dimakan, tapi liurnya dianggap menjijikkan ?"39

3. Mendahulukan amal penduduk Madinah atas khabar ahad. Dalam pandangan Malik, amal penduduk Madinah kekuatannya mendekati mutawatir, sebab apa yang mereka lakukan berdasarkan petunjuk Nabi. Misalnya, ia menolak adanya khiyar majlis, sementara ada hadist yang berbunyi penjual dan pembeli memiliki hak khiyar sepanjang masih berada pada satu majlis. Hal itu menyalahi praktek penduduk Madinah yang tidak mengenal khiyar majlis. ${ }^{40}$

Banyak kalangan menilai bahwa Malik melarang puasa Shawal selama enam hari atas dasar pertimbangan maslahah karena dikhawatirkan masyarakat menganggapnya sebagai kewajiban 'lanjutan' dari Ramadhan, sehingga fatwa tersebut dinilai menyalahi hadist Nabi. Dugaan tersebut dibantah oleh Ibn Rushd. Ia 'menduga keras' bahwa Malik meragukan kesahihan hadist tersebut. ${ }^{41}$

Adapun 'dugaan' kalangan yang menilai bahwa Malik men-takhsis nas 'am dengan maslahah adalah berdasarkan fatwa Malik yang tidak mewajibkan para ibu dari kalangan keluarga 'kelas elite' untuk menyusui sendiri anaknya. Fatwa tersebut dinilai menyalahi Q.S. 2:233. Dugaan tersebut tidak benar, sebab dalam pandangan Malik sebagaimana juga ulama' Syafi'iyah, ayat terebut tidak menunjukkan kewajiban seorang ibu untuk menyusui anaknya. Ayat tersebut berbentuk mujmal, sehingga mengandung kemungkinan wajib menyusui dan tidak wajib menyusui. Berdasarkan 'urf yang berlaku saat itu, maka ia menfatwakan bahwa para ibu dari kalangan elite tidak harus menyusui. Dengan demikian, maka fungsi 'urf tersebut adalah sebagai penjelas terhadap ke-mujmal-an nas, bukan men-takhsis keumuman nas. ${ }^{42}$

Dengan demikian, jelas bahwa Malik menempatkan nas dan ijma' di atas maslahah. Penolakannya terhadap hadist ahad sebagaimana contoh di atas, bukan karena ia mendahulukan maslahah atas khabar ahad, tetapi karena khabar tersebut tidak memenuhi syarat-syarat untuk bisa diterima, sehingga diragukan bahwa ia berasal dari Nabi. Dalam pandangan Malik, zanni sebagaimana khabar ahad, yang bertentangan dengan asal yang qat'i, harus ditolak. Sebab, ia berarti menyalahi prinsip-prinsip syari'ah, sementara menyalahi prinsip syari'ah tidak sah. Bagaimana ia bisa disebut syari'ah jika menyalahi prinsip syari'ah? Dengan kata lain, terjadi pertentangan antara dalil qat'i dan dalil zanni sehingga yang qat'i yang

\footnotetext{
${ }^{39}$ Ibid., 20-1. lihat juga al-Shatibi, al-Muwafaqat, vol. 3, 15.

${ }^{40}$ Al-Shatibi, al-Muwafaqat, vol. 3, 15. Lihat juga al Buti, Dawabit, 188-190.

${ }^{41}$ Ibn Rushd, Bidayah, vol. 1, 225.

${ }^{42}$ Al-Buti, Dawabit, 340. 
harus dimenangkan. Adapun jika ada dalil lain yang mendukung kesahihannya, maka Malik tidak menolaknya. ${ }^{33}$

Berbeda dengan Malik, al-Tufi tegas-tegas menempatkan maslahah pada posisi yang lebih kuat dibanding nas dan ijma'. Karena itu, ketika terjadi pertentangan antara maslahah di satu pihak dengan nas/ijma' di pihak lain, maka maslahah yang harus didahulukan. Hal ini diantaranya terlihat dari pernyataannya yang mengatakan bahwa konsepnya bukanlah konsep maslahah mursalahnya Malik, tetapi lebih luas dari itu, yaitu mengembalikan kepada nas dan ijma' dalam persoalan ibadah, sementara dalam persoalan mu'amalah dikembalikan sepenuhnya pada maslahah. ${ }^{4}$

Berdasarkan penelitian al-Tufi, dalil syar'i ada 19 (sembilan belas), ${ }^{45}$ sebagian disepakati sementara sebagian yang lain diperselisihkan. Dari 19 dalil tersebut yang terkuat adalah nas dan ijma'. Namun demikian, adakalanya keduanya sejalan dengan maslahah, adakalanya berseberangan dengan maslahah. Jika keduanya sejalan dengan maslahah, berarti tidak ada persoalan karena telah ada kecocokan di antara tiga dalil, yaitu nas, ijma', serta maslahah. Jika keduanya berseberangan dengan maslahah, maka wajib mendahulukan maslahah dengan jalan bayan dan takhsis, bukan dengan menghapus, atau mengabaikan keduanya sebagaimana mendahulukan sunnah atas Al-Qur'an dengan jalan bayan. Walhasil maslahah adalah dalil syar'i paling kuat, sebab yang lebih kuat daripada yang terkuat adalah yang paling kuat. ${ }^{46}$

Mendahulukan maslahah daripada dalil, tidak bisa disebut sebagai sebuah bentuk penyimpangan, sebab pada dasarnya kita meninggalkan dalil dengan dalil yang lebih kuat. ${ }^{47}$ Disamping itu, maslahah merupakan tujuan dari penetapan hukum terhadap mukallaf dalam persoalan mu'amalah, sementara dalil yang lain hanyalah perantara. Dengan demikian, tujuan harus didahulukan daripada perantara. 48

Dari sini, maka terlihat perbedaan yang sangat tajam antara konsep al-Tufi dengan Malik, sebab dengan demikian berarti al-Tufi menggunakan maslahah, baik dalam persoalan yang dibicarakan oleh nas/ijma' ataupun tidak. Penolakannya membagi maslahah menjadi mu'tabarah, mulghah, dan mursalah melahirkan kesimpulan bahwa kedudukan maslahah menjadi sejajar dengan nas sebagai sumber hukum sebab maslahah tidak membutuhkan konfirmasi dari nas, bahkan lebih kuat jika menyangkut persoalan mu'amalah. Dengan kata lain, nas/ijma' merupakan sumber hukum persoalan ibadah dan muqaddarat, sementara

\footnotetext{
${ }^{43}$ Abu Zahrah, Malik, 241.

${ }^{44}$ Ibid., 764.

${ }^{45}$ Selengkapnya lihat di al-Tufi, Risalah, 746-9.

${ }^{46}$ Ibid., 746-754.

${ }^{47}$ Ibid., 762.

${ }^{48}$ Ibid., 768.

145
} 
maslahah merupakan sumber hukum persoalan mu'amalah. Sedangkan Malik menjadikan maslahah hanya sebagai 'metode' dalam memahami nas, sebagaimana qiyas, istihsan, sadd aldhari'ah, dan lain-lain. Muncul satu pertanyaan, jenis maslahah apakah yang dimaksud oleh alTufi?

Sebagaimana disebutkan di awal, al-Tufi menolak pembagian kualitas maslahah menjadi daruri, haji, dan tahsini. Ia juga dengan tegas-tegas mengatakan bahwa penentuan maslahah dalam persoalan mu'amalah sepenuhnya ditentukan oleh akal. Di sini terlihat kembali kesembronoan al-Tufi, sebab dengan demikian, berarti maslahah yang dimaksud oleh al-Tufi harus di dahulukan atas nas dan ijma' adalah maslahah dalam kualitas apapun, baik maslahah tersebut berkualitas daruri, haji, ataupun hanya sebatas tahsini.

'Ali al-Rabi'ah dalam kitabnya Adillat al-Tasyri' bahkan menyimpulkan bahwa mas\}lah\}ah yang dimaksud al-Tufi harus di dahulukan atas nas dan ijma' adalah maslahah yang berkualitas haji dan tahsini, sebab kedua jenis maslahah inilah yang dinilai memiliki kemungkinan untuk tidak sejalan dengan maslahah. Hal itu terlihat dari pertanyaan al-Tufi yang mengatakan bahwa maslahah dan dalil-dalil yang lain, bisa jadi sejalan dengan maslahah, tetapi bisa jadi pula bertentangan dengan maslahah. Jika ia sejalan dengan maslahah, maka harus diikuti sebagaimana sejalannya nas/ijma' dengan maslahah dalam lima persoalan asasi yang bersifat daruri, seperti qisas, hukum potong tangan, dan lain-lain. Jika ternyata bertentangan dengan maslahah, sepanjang memungkinkan untuk dikompromikan, maka harus dikompromikan, tetapi jika tidak mungkin dikompromikan, maka maslahah yang harus didahulukan. ${ }^{49}$ Pernyataan tersebut dalam pandangan al-Rabi'ah melahirkan kesimpulan bahwa maslahah daruri pasti sejalan dengan maslahah, yang dengan demikian, berarti maslahah haji dan tahsini-lah yang harus didahulukan atas nas dan ijma' itu. ${ }^{50}$ Pertanyaan lebih lanjut adalah benarkah klaim al-Tufi bahwa teorinya tersebut hanya sebatas takhsis?

Dalam kitab 'Ilm Us\}ul al-Fifh, 'Abd al-Wahhab khallaf menjelaskan perbedaan antara takhsis dan naskh juz'i. Takhsis berarti hukum yang dimaksud oleh Syari' sejak awal pensyari'atannya adalah hukum yang telah di-takhsis, sementara naskh berarti membatalkan hukum yang telah ditetapkan sejak awal karena adanya tuntutan kemaslahatan. ${ }^{51}$ Dalam teorinya, al-Tufi mengatakan bahwa suatu nas yang jika diterapkan ternyata menyalahi mas\}lah\}ah, maka nas tersebut harus di-takhsis ${ }^{52}$ sehingga untuk kasus tersebut, nas itu tidak berlaku. Dari pernyataan itu nampaknya teori al-Tufi lebih tepat disebut sebagai naskh

\footnotetext{
${ }^{49}$ Al-Tufi, Risalah, 767.

${ }^{50}$ Al-Rabi'ah, Adillah, 200-1.

${ }^{51}$ Khallaf, 'Ilm, 187. lihat juga halaman 225 pada buku yang sama.

${ }^{52}$ Khallaf, Masadir, 109. 
(pembatalan) karena sifatnya kondisional. Artinya, pengecualian itu tidak bisa diklaim sebagai hukum yang telah dimaksudkan sejak awal oleh Syari' karena jika demikian, pasti dalil dimaksud segera diiringi oleh dalil takhsis-nya. Teori itu juga tidak bisa dikategorikan dalam persoalan darurat, sebab maslahah yang diakui al-Tufi tidak terbatas pada maslahah yang bersifat daruri, tapi juga haji dan tahsini. Adapun dalam kaitannya dengan ijma', ijma' adalah dalil qat'i dari segala sisi, ${ }^{53}$ maka dari sisi mana ia harus di-takhsis?

Pertanyaan lebih lanjut lagi adalah nas apakah yang dimaksud oleh al-Tufi harus 'dikalahkan' oleh maslahah? Apakah nas yang memiliki indikasi zanni, ataukah nas yang memiliki indikasi qat'i?

Ketika memaknai hadits La darar wa la dirar, al-Tufi mengatakan bahwa hadist tersebut mengisyaratkan untuk menghapus darar (bahaya) dan mafsadah. Isyarat ini bersifat umum, kecuali ada dalil yang bersifat khusus. Hal ini menunjukkan keharusan mendahulukan hadith tersebut atas segala macam dalil syar'i serta men-takhsis dalil syar'i tersebut dengan hadist ini.

Artinya, seandainya ada dalil syar'i mengandung darar, jika darar tersebut kita hilangkan dengan hadist ini (dengan jalan bayan dan takhsis), berarti kita telah mengamalkan dua dalil. Jika darar tidak kita hilangkan berarti kita telah mengabaikan salah satu dari dua dalil, yaitu hadist ini. Sementara itu tidak diragukan bahwa tindakan pengkompromian lebih utama daripada mengabaikan salah satunya. Penghapusan darar merupakan suatu keharusan agama. Beberapa ayat Al-Qur'an yang menunjukkan hal tersebut di antaranya Q.S. 2;185; 22:78; 5:6, dan lain-lain. Secara lebih rinci, al-Tufi menjelaskan bahwa, nas bisa jadi tidak mengandung darar (bahaya) secara keseluruhan, atau sebaliknya. Jika tidak mengandung darar secara keseluruhan, berarti keduanya sejalan dengan maslahah. Jika mengandung darar, dan darar tersebut meliputi seluruh madlul (yang ditunjuk) nas, maka naslah yang harus diikuti, seperti hudud dalam persoalan jinayah. Namun jika darar tersebut hanya meliputi sebagian dari yang ditunjuk (madlul) oleh nas, dan yang menghendakinya adalah dalil khas, maka dalil tersebut yang harus diikuti. Tetapi ketika tidak ada dalil khas yang menghendakinya, ia harus di-takhsis dengan hadith la darar wa la dirar, yang berarti maslahah didahulukan. Satu hal yang perlu dicatat adalah bahwasanya seluruh nas mengandung maslahah. Ijma'pun didasarkan pada maslahah. Karena itu, suatu yang mustahil jika kemudian Allah mengabaikan kemaslahatan hamba-Nya. ${ }^{54}$

Secara eksplisit pernyataan al-Tufi tidak menunjuk pada bentuk nas tertentu. Karena itu ulama' berbeda pendapat tentang bentuk nas yang dimaksud al-Tufi. Abu Zahrah

\footnotetext{
${ }^{53}$ Ibid., 46.

${ }^{54}$ Al-Tufi, al-Risalah, 752-3.

147
} 
memahaminya nas qat'i, sementara ulama'lain, di antaranya Hamid Hasan dan al-Yubi, memahaminya nas zanni. 55 Pendapat terakhir nampaknya lebih kuat.

Hal itu bisa dilihat dari pernyataannya yang berbunyi “...jika darar tersebut meliputi sebagian dari yang ditunjuk (madlul) oleh nas..." Artinya lafaz suatu ayat atau hadist tersebut berbentuk 'am, sedangkan darar-nya hanya meliputi sebagian yang ditunjuk oleh nas dimaksud, sementara lafaz 'am dalalahnya adalah zanni menurut jumhur ulama' us\}ul.56 Apalagi diperkuat lagi dengan pernyataannya bahwa mendahulukan maslahah tersebut sebatas takhsis dan bayan. Disamping itu, ia juga mengatakan jika dalam persoalan itu terdapat dalil khas, maka harus mengikuti dalil khas tersebut. Artinya, ia tidak mengandaikan terjadinya kontradiksi antara dalil khas yang dalalahnya qat'i dengan maslahah, sebab jika yang ia maksudkan adalah dalil khas, tak bisa tidak, maka tindakan tersebut adalah tindakan pengabaian terhadap dalil. Dengan demikian, berarti al-Tufi mendahulukan maslahah atas dalil 'am, karena dalil 'am, dalalahnya zanni. Tetapi jika dalil tersebut merupakan dalil khas, maka dalil tersebut yang harus didahulukan, sebab dalil khas, dalalahnya qat'i.57 Namun demikian, tetap menjadi tidak penting, apakah nas yang dimaksud oleh al-Tufi berupa nas zanni atau qat'i, sebab klaim al-Tufi bahwa teorinya itu adalah sebatas takhsis tidak tepat sebagaimana dijelaskan di atas.

Di antara kelemahan teori al-Tufi adalah kesulitannya menghindar dari kontradiksikontradiksi dalam pemikirannya. Misalnya, ia mengandaikan kemungkinan nas mengandung darar. Pada bagian lain ia mengatakan bahwa seluruh nas mengandung maslahah. Ijma'pun didasarkan pada maslahah dan suatu hal yang mustahil bahwa Syari' mengabaikan kemaslahatan hamba-hamba-Nya. Pernyataan ini mendapat serangan dari al-Buti. Dalam pernyataannya ia mengatakan, kalau memang seluruh nas mengandung maslahah, berarti kemaslahatan yang bertentangan dengan nas adalah kemaslahatan yang tidak hakiki. Atau sebaliknya, dasar pijakan bahwa syari'ah datang untuk kemaslahatan, gugur. ${ }^{58}$

Kontradiksi berikutnya adalah pernyataannya bahwa maslahah adalah tujuan sementara dalil yang lain adalah perantara. Pernyataan ini berbeda dengan definisi yang dikemukakannya yang menyatakan bahwa maslahah adalah 'sebab yang menghantar pada maksud Syari'. Jika dalil yang lain dianggap sebagai perantara, maka maslahah juga harus dianggap sebagai perantara karena ia sama-sama dalil syar'i sebagaimana disebutnya di atas.

\footnotetext{
${ }^{55}$ Lihat Abu Zahrah, Malik, 317. lihat juga Hassan, Nazariyah, 538 dan al-Yubi, Maqasid, 539-40.

${ }^{56}$ Zaydan, al-Wajiz, 317.

${ }^{57}$ Hassan, Nazariyah, 539-540.

${ }^{58}$ Al-Buti, Dawabit, 209.
} 
Kebangkrutan lain dari teori al-Tufi adalah ia sama sekali tidak mengemukakan satu contoh pun. Minimal, hal itu menunjukkan bahwa ia tidak memiliki kepedulian terhadap produk hukum. Lebih parah lagi berarti ia gagal membuktikan adanya nas yang bertentangan dengan maslahah. Sangat masuk akal jika kemudian dengan sengit Zayd menuding bahwa konsep al-Tufi dibangun diatas landasan mimpi/angan-angan (asas mauhum la wujud lah).59

Adapun alasan al-Tufi memprioritaskan maslahah atas nas dan ijma'60 adalah sebagai berikut:

1. Ijma' diperselisihkan kehujjahannya, sementara maslahah disepakati termasuk oleh mereka yang menentang ijma'. Dengan demikian, maka ijma' adalah sesuatu yang disepakati. Berpegang kepada sesuatu yang disepakati lebih utama daripada berpegang kepada sesuatu yang diperselisihkan. Jika melihat pernyataan ini, berarti menunjukkan kurangnya riset akademik yang dilakukan oleh al-Tufi. Sebab, Syi'ah jelas-jelas menentang maslahah karena maslahah adalah ra'yu, sementara agama tidak boleh didasarkan pada ra'yu. Demikian juga al-Nazzam. Ketegasannya dalam menolak ra'yu sama dengan ketegasannya dalam menolak kemungkinan terjadinya ijma'.61 Namun jika melihat pernyataannya di bagian lain, ia mengatakan bahwa seluruh ulama' sepakat bahwa ijma' didasarkan pada maslahah, kecuali penentang ijma', di antaranya Zahiriyah. ${ }^{62}$ Pernyataan ini menunjukkan bahwa Zahiriyah diakuinya tidak mengakui mas\}lah\}ah. Dari sini berarti pernyataannya kembali konradiktif. Al-Zuhayli punya pendapat lain lagi dalam menghadapi persoalan ini. Ia mengatakan: “ Jika al-Tufi berpendapat bahwa maslahah merupakan sesuatu yang disepakati, bukankah berarti ia termasuk bagian dari ijma?' Jika ijma' merupakan sesuatu yang diperselisihkan, bukankah ia termasuk bagian yang diperselisihkan itu? Dengan demikian, batallah teorinya, bahwa salah satu dari kedua dalil tersebut lebih unggul". ${ }^{63}$

2. Nas-nas mengandung banyak pertentangan dan hal inilah, yang salah satunya, menjadi sebab terjadinya perbedaan pendapat yang tercela dalam hukum menurut pandangan syara'. Sementara itu, memelihara maslahah secara substansial merupakan sesuatu yang hakiki, yang tidak diperselisihkan. Dengan demikian, pengutamaan maslahah ini merupakan sebab terjadinya kesepakatan yang dikehendaki oleh syara'. Tidak jelas apakah yang dimaksud al-Tufi dengan nas di atas adalah menyangkut substansinya atau sebatas persepsi para mujtahid dalam menyikapi sebuah nas. Bila yang dimaksud adalah yang pertama, maka tak pelak pernyataan tersebut adalah pernyataan yang sangat berbahaya,

\footnotetext{
${ }^{59}$ Zayd, al-Maslahah, 135.

${ }^{60}$ Al-Tufi, Risalah, 760-1.

${ }^{61}$ Khallaf, 'Ilm, 48.

${ }^{62}$ Al-Tufi, "Risalah" dalam al-Maslahah, 215.

${ }^{63}$ Al-Zuhayli, Usul, vol. 2, 820-1.
} 
karena jelas-jelas melanggar Q.S. 4:82. Sebaliknya bila yang dimaksudkan adalah yang kedua, maka pendapat tersebut tidak berbeda dengan para fukaha' umumnya. ${ }^{64}$ Bedanya, menurut al-Tufi perbedaan semacam itu tergolong negatif dan tercela dalam Islam. Ini yang banyak menimbulkan asumsi bahwa yang dimaksud al-Tufi adalah menyangkut substansi nas. Sebab, perbedaan pemahaman terhadap nas dalam hukum-hukum yang menyangkut cabang memiliki dimensi rahmah. Atau paling tidak, ditolerir oleh ajaran agama sebagai cerminan dari elastisitas ajaran Islam dalam menyikapi fenomena sosial yang terus berubah, bukan berdimensi negatif sebagaimana yang diduga al-Tufi.

3. Sesungguhnya telah terjadi nas-nas dalam sunnah yang ditentang oleh maslahah dalam beberapa hal. Misalnya, Rasulullah memerintahkan Abu Bakar untuk menyampaikan hadist (من قال لاإله إلا الله دخل الجنة) tetapi dilarang oleh Umar karena dikhawatirkan masyarakat malas beramal karena mengandalkan hadith tersebut. Pijakan dalil inipun juga memiliki kelemahan. Sebab, sikap Umar ternyata mendapat legitimasi dari Nabi. Dalam kajian ilmu hadist, apa yang dilakukan para sahabat tersebut bukanlah maslahah dalam pengertian yang independen, melainkan maslahah yang sudah mendapat pengakuan dari Nabi (taqrir). 66

Walaupun tidak secara spesifik mengulas argumen al-Tufi, Munawir Sjadzali mendukung pemikiran tersebut. Dalam persoalan mu'amalah, wahyu-wahyu turun sebagai tanggapan terhadap persoalan masyarakat yang terjadi saat itu. Berarti ia sangat memperhatikan situasi dan kondisi lapangan. Karena itu, memahami nas haruslah secara kontekstual sesuai dengan tingkat peradaban dan kemajuan intelektualitas manusia, karena jika tidak, maka hukum Islam akan kehilangan relevansinya dengan dunia dimana kita hidup sekarang.

Untuk melegitimasi argumennya, Munawir menunjuk konsep naskh dalam Al-Qur'an. Konsep naskh diperkenalkan Al-Qur'an dan hadist akibat adanya perubahan-perubahan sosial. Jika dalam masa 22 tahun turunnya Al-Qur'an saja Allah membatalkan/merubah sekian banyak ketentuan-ketentuan hukumnya, maka suatu hal yang mustahil dalam masa sekian ratus tahun sesudah turunnya tidak terjadi perubahan hukum. ${ }^{67}$

Sayang sekali bahwa dukungan Munawir tidak dijabarkan lebih lanjut. Sebab, teori alTufi kemudian ia bawa-bawa kepada persoalan-persoalan yang sudah ditentukan kadarnya

\footnotetext{
${ }^{64}$ Al-Shatibi, al-Muwafaqat, vol. 4, 217.

${ }^{65}$ Abu Zakariya Muhy al-Din Yahya bin Sharaf al-Nawawi, Syarh Sahih Muslim, (Beirut: Dari Ihya' al-Turath al'Arabi, $1347 \mathrm{H})$, vol. 1, 59

${ }^{66}$ Ahmad Umar Hashim, Qawa 'id fi Usul al-Hadits (t.t.: Dar al-Fikr, t.t.), 138.

${ }^{67}$ Munawir Sjadzali, Kontekstualisasi Ajaran Isla>m, ed. Wahyuni Nafis, (Jakarta: IPHI-Paramadina, 1995, 70-5. 150
} 
(muqaddarat), seperti pembagian waris.68 Padahal al-Tufi sendiri menolak mengotak-atik persoalan-persoalan yang sudah ditentukan kadarnya.

Rasanya tidak akan sedikit orang yang berpendapat bahwa argumen-argumen al-Tufi kurang berbobot, kalau tidak bisa dikatakan dangkal, sehingga sangat mudah untuk dipatahkan. Apalagi kontradiksi-kontradiksi pernyataannya sangat mudah untuk ditangkap oleh siapapun yang membacanya. Al-Tufi terkesan kehilangan pijakan dalam membangun pemikirannya, sehingga sering tidak konsisten.

Kemampuan akal dalam menentukan baik dan buruk akan sangat subyektif sekali. Kalau akal dapat menentukan baik buruk, maka tentunya tidak perlu lagi diutus seorang Rasul. Padahal Al-Qur'an (Q.S 5:99) tegas-tegas mengatakan bahwa tugas seorang Rasul adalah 'menyampaikan' ajaran-Nya. Penolakan al-Tufi terhadap pembagian mas\}lah\}ah menjadi mu'tabarah, mulghah dan mursalah, adalah suatu tindakan yang 'gegabah' dan terkesan 'tanpa berpikir panjang', sebab akibatnya jelas sangat riskan karena ia menempatkan akal (maslahah) pada posisi yang sejajar dengan nas\}, bahkan lebih kuat jika menyangkut mu'amalah sebagaimana dijelaskan di atas. Persoalan ini bukan persoalan sepele. Jika diungkapkan dalam bahasa yang ekstrim, berarti akal dijadikan sebagai dalil hukum.

Sebagaimana yang dikemukakan al-Shatibi di atas, akal bukanlah Syari', sementara persoalan ini adalah persoalan syar'i. Karena itu, akal tidak boleh melepaskan ketergantungan sama sekali terhadap nas. Al-Qur'an (4:59) sendiri mengatakan “...taatlah kalian kepada Allah, kepada Rasul dan kepada uli al-amr..." yang dalam pandangan para ulama' menunjukkan bahwa nas merupakan pijakan pertama dan utama dalam mengambil kesimpulan hukum, baik nas tersebut bersifat qat'i maupun zanni. ${ }^{69}$ Perbedaannya adalah, nas-nas qat'i tidak bisa dimasuki nalar manusia (ijtihad), sementara terhadap nas-nas zanni, terbuka peluang yang sangat luas bagi nalar manusia untuk memasukinya. Dari sisi ini, teori al-Tufi yang hanya terbatas pada nas zanni tidaklah terlalu 'seram' sebagaimana gambaran umum selama ini.

Namun demikian, perlu diingat kembali bahwa ijtihad terhadap nas-nas zanni tetap dalam pengertian upaya memahami nas tersebut, sehingga secara logika, kesimpulan yang dihasilkan, tidak akan berseberangan dengan nas dimaksud. Mislanya, Q.S. 5:6 tentang kewajiban mengusap kepala dalam wudu'. Ayat tersebut berindikais zanni, sebab lafaz "bi" pada lafaz bi ru'usikum, mengandung arti 'seluruh' atau 'sebagian'. Dengan demikian, tugas seorang mujtahid hanya beruasaha untuk mengetahui, apakah yang dimaksud oleh ayat tersebut seluruh kepala ataukah sebagian kepala saja yang harus diusap ketika seseorang

\footnotetext{
${ }^{68}$ Munawir Sjadzali, Ijtihad Kemanusiaan, (Jakarta: Paramadina, 1997), 6-8.

${ }^{69}$ Khallaf, 'Ilm, 21.
} 
melakukan wudu'.70 Dengan demikian pula, ia tidak boleh menyimpulkan bahwa mengusap kepala bisa ditiadakan dalam wudu', misalnya.

Mengingat klaim al-Tufi bahwa teorinya tersebut hanyalah sebatas takhsis tidak tepat, maka menjadi tidak penting apakah nas yang dimaksudkannya adalah nas qat'i ataupun zanni, sebab teori al-Tufi lebih tepat disebut sebagai pembatalan terhadap nas. Padahal, siapa pun berpendapat bahwa yang berhak melakukan pembatalan terhadap hukum Allah, hanyalah Allah sendiri. ${ }^{71}$

Teori al-Tufi menjadi lebih riskan karena dia menggebyah-uyah seluruh jenis maslahah. Sehingga mas\}lah\}ah tahsini-pun yang fungsinya hanya sekedar 'penggembira' memiliki kans untuk 'melawan' nas dan ijma'. Dari sisi ini, maka tak pelak teori al-Tufi memang sangat seram.

Pemikiran al-Tufi sangat mungkin dipengaruhi oleh situasi politik saat dia hidup. Al-Tufi hidup dimana ummat Islam berada dibawah cengkraman penjajah Mongol. Kedigdayaan Islam yang selama berabad-abad merajai dunia hancur lebur dibawah kaki bangsa Jengis Khan itu. Nampaknya jiwa al-Tufi memberontak melihat situasi itu dan ingin mengembalikan pamor Islam yang sudah amblas. Sangat mungkin ia berkesimpulan bahwa situasi itu akibat umat Islam terlalu terikat pada nas-nas yang sudah baku, sehingga ia berpandangan bahwa umat Islam harus berani melepaskan diri dari 'kungkungan' nas-nas itu jika ingin maju dan mengembalikan kejayaan yang pernah diraihnya. Apalagi perkembangan ilmu agama pada saat itu mengalami kelesuan yang luar biasa dimana para ulama' lebih memilih bersikap taklid. Tidak tertutup kemungkinan ia melihat bahwa keterpakuan umat Islam terhadap teks-teks AlQur'an akan menyebabkan umat Islam terus ketinggalan. Namun sayang sekali al-Tufi kebablasan sehingga ia berani melanggar pagar yang seharusnya tidak boleh dilewatinya. Bukan hanya oleh dia. Tapi juga oleh siapapun yang meyakini bahwa Al-Qur'an dan al-sunnah adalah pijakan dalam setiap sendi kehidupan seorang yang mengaku dirinya muslim.

Hal ini sangat berbeda dengan Malik yang hidup pada masa kejayaan Islam mencapai puncaknya. Lebih-lebih Malik hidup di Madinah yang notabene merupakan 'rumah Nabi'. Menyaksikan kejayaan Islam sedemikian rupa, tentunya semakin meyakinkan Malik bahwa Al-Qur'an dan al-sunnah adalah pegangan umat Islam yang tidak boleh dikalahkan oleh apapun dan siapapun.

Berdasarkan pembahasan di atas, teori Malik yang hanya menggunakan maslahah dalam persoalan yang tidak dibicarakan secara formal oleh nas ataupun ijma' jelas lebih kuat. Sebab, dengan teori ini, maka maslahah Malik tidak akan punya peluang untuk melawan nas/ijma'.

\footnotetext{
${ }^{70}$ Khallaf, Masadir, 9.

${ }^{71}$ Manna'al-Qattan, Mabahith fi 'Ulum Al-Qur'an (Beirut:Mu'assasah al-Risalah, 1991), 236.
} 
Apalagi maslahah Malik pada dasarnya merupakan metode dalam memahami nas. Bukankah al-Tufi sendiri mengatakan bahwa seluruh nas mengandung maslahah?

\section{F. Kesimpulan}

1. Malik terlihat jauh lebih hati-hati dibandingkan al-Tufi. Ia tetap berjalan pada koridor yang menjadi pegangan ulama' selama ini. Sementara al-Tufi lebih berani, bahkan cenderung gegabah dalam menelurkan gagasannya. Maslahah dalam konsep Malik adalah maslahah yang disimpulkan dari sejumlah nas. Dengan demikian, maslahah hanya dijadikan sebagai 'metode' dalam memahami nas, bukan sumber hukum yang berdiri sendiri. Adapun alTufi menjadikan maslahah sebagai sumber hukum yang berdiri sendiri, sebagaimana halnya Al-Qur'an dan Sunnah.

2. Konsep Malik lebih kuat dibandingkan konsep al-Tufi, sebab Malik tetap menempatkan nas/ijma' sebagai landasan utama dan pertama dalam menetapkan hukum. Hal tersebut sesuai dengan Q.S. 4;59. Sikap Malik itu juga sejalan dengan praktek yang dilakukan oleh para sahabat yang pada dasarnya mengacu pada tuntunan Nabi. Malik hanya menggunakan maslahah dalam persoalan-persoalan yang tidak dibicarakan secara formal oleh nas dan ijma' sehingga dalam konsep Malik, maslahah tidak memiliki peluang untuk melawan nas dan ijma'. Apalagi maslahah yang dimaksudkan oleh Malik adalah maslahah yang digali dari sejumlah nas, karena pada dasarnya maslahah tersebut hanyalah sebatas 'metode' dalam memahami nas. Berbeda dengan konsep Malik, konsep al-Tufi tidak memiliki landasan kuat. Menempatkan maslahah pada posisi sejajar dengan nas merupakan pelanggaran terhadap syari'ah. Ketidakmampuannya memberikan satu contoh pun merupakan sisi lain dari kelemahan teorinya yang cukup mendasar. 


\section{DAFTAR PUSTAKA}

Al-Abd Salam, Muhammad 'Ijaz al-Din 'Abd. Qawa'individu al-Ahkam fi Masalih al-Ana am. Vol 1, Beirut: Dar al-Kutub al-'Ilmiyah, t.t.

Al-Alusi, Shihab al-Din al-Sayyid Mahmud. ruh al-Ma'ani fi Tafsir Al-Qur'an al-Azim wa al-Sab' al-Ma'ani. Vol. 11, t.t.: al-Muniriyah, t.t.

Al-Amidi, Say al-Din Abi al-Hisan 'Ali bin Abi. Muhammad. 1996. alIhkam fi Usul al-ahkam, vol. 4, Beirut: Dar al-Fikr.

Al-Buti. 1979. Dawabit, 23. lihat juga 'Abd al-Aziz bin 'Abd al-Rahman bin 'Ali al-Rabi'ah, Adillat al-Tashri', Beirut: Mu'assasah al-Risalah.

Al-Buti, Muhammad Sa'id Ramdan. Dawabit al-Maslahah (t.t.: Mu'assasah al-Risalah, t.t.), 23

Al-Dimasyqi, Ibn Kathir. Al-Bidayah wa al-Nihayah. Vol 13. Beirut: Dar al-Kutub al-`Ilmiyah, t.t.

Al-Ghazali. al-Mustafa, 174-5. lihat juga Abu> Ishaq al-Shatibi, al-Muwafaqat fi Usul Shari'ah, vol. 2, Beirut: Ar al-Kutub al'Ilmiyah, t.t.

Al-Ghozali, AbuHamid bin Muhammad. al-Mustafa, Beirut: Dar al-Kutub al-'Ilmiyah, t.t.

Al-Mahalli, Jalal al-Din. Syarh al-Waraqat. Semarang: Maktabah Usaha Keluarga, t.t.

Al-Rahman, Jalal al-Din 'Abd. 1983. al-Masalih al-Mursalah wa Makanatuha fi al-Tashri'i, t.t.:Matba' antara al-SA'adah.

Al-Shak'ah, Mustafa. 1991. al-A'immah al-Arba'ah, Kairo: Dar al-Kutub al-Misr.

Al-Shatibi, Abu Ishaq. al-I'tisam. Vol. 2, Riyad: Maktabat al-Riyal al-Hadithah, t.t.

Al-Syafi'i, Muhammad Idris. al-Risalah, t.t.: Dar al-Fikr, t.t

Al-Tufi, Najm al-Din. 1906. "Risalah al-Maslahah" dalam al-Manar, vol. 9, juz 10,ed. Muhammad Rasyid Rida, Mesir; al-Manar.

Al-Tufi, Najm al-Din. 1989. Syarh Mukhtasar al-Rawdah. Vol I, Tahqiq Ibrahim bin 'Abdullah, t.t.: al-Shirq al-Awsat.

Al-Tufi, Najm al-Din. 1989. Syarh Mukhtas\}ar al-Rawdah. Vol. 3, Tahqiq 'Abdullah bin 'Abdal Muhsin al-Turki, Beirut: Mu'assasah al-Risalah.

Al-Yubi, Muhammad Sa'd bin Ahmad bin Masyarakat. 1998. Maqasid al-Shari'antara alIslamiyah, Riyad: Dar al-Hijrah.

Al-Zarqani, Muhammad. Syarh al-Zarqani 'Ala Muwa al-Imam Malik. Vol .2. t.t.: Dar al-Fikr, t.t.

Al-Zuhayli, Wahbah. 1986. Usul al-Figh al-Islami. Vol. 2. Beirut: Dar al-Fikr al-Mu'asir.

Ali, K. 1997. Sejarah Islam, Jakarta: Raja Grafindo Persada.

Hasan, Husain Hamid. 1971 Nazariyat al-Maslahah fi al-Fiqh al-Islami. Beirut: Dar al-Nahdah al'Arabiyah. 
Hasjmy, A. 1995. Sejarah Kebudayaan Islam. Jakarta: Bulan Bintang.

Hassan, Ibrahim. 1989. Sejarah dan Kebudayaan Islam. Yogyakarta: Kota Kembang.

Khallaf, Abd al-Wahhab. 1972. Masadir al-Tashri' al-Islami fi Ma La Nas Fih, Kuwait: Dar alQalam.

Munawwir, Acmad Warson. Kamus al-Munawwir, t.t.: Pustaka Progresif, t.t.

Nasution, Harun. 1986. Teologi Islam, Aliran-Aliran, Sejarah, Analisa, Perbandingan. Jakarta: UIPress.

Rahmat, Jalaluddin. 1995. Tinjauan Kritis atas Sejarah Figh, dalam Konstekstualisasi Doktrin Islam Dalam Sejarah, cd. Budhy Munawar Rahman. Jakarta: Paramadina.

Shalabi,Muhammad Mustafa. 1981. Ta'li al-Ahkam, Beirut: Dar al-Nahdat al-'Arabiyah.

Syalabi, A. 1995. Sejarah Kebudayaan Islam Vol 2, Jakarta: Al-Husna Zikra.

Towana, Muhammad. al-Ijtihad wa Mada Hajatina Ilayh fi hadha al-'Asr, t.t.: Dar al-Kutub alHadithah,t.t

Usman, Iskandar. 1994. Istihsan dan Pembaharuan Hukum Islam. Jakarta: Raja Grafindo Persada.

Uwaydah, Kamil Muhammah 'Uwaydah. 1992. Malik bin Anas Imam Dapatr al-Hijrah,, Beirut: Dar al-Kutub al-'Ilmiyah.

Zahra, Muhammad Abu. Ushul al-Figh, t.t: Dar al-Fikr al'Arabi, t.t.

Zahrah. Muhammad Abu. Malik, Hiyatuh wa 'Asruh, 'Ara'uh wa Fiqhuh, t.t. Dar al-Fikr al-'Araby, t.t

Zaydan, Abd al-Karim. al-Wajiz Usul al-figh. t.t.: Mu'assasah al-Risalah, t.t.

Zayd, Mustafa. 1963. al-Maslahah fi al-Tasyri' al-Islami wa Najm al-Din al-Tufi. t.t.: Dar al-Fikr al'Arabi. 